\title{
Morphoanatomical responses induced by excess iron in roots of two tolerant grass species
}

\author{
Talita Oliveira de Araújo • Larisse de Freitas-Silva • Brenda Vila Nova Santana • \\ Kacilda Naomi Kuki • Eduardo Gusmão Pereira • Aristéa Alves Azevedo • \\ Luzimar Campos da Silva
}

Received: 30 April 2014 / Accepted: 20 August 2014 / Published online: 31 August 2014

(C) Springer-Verlag Berlin Heidelberg 2014

\begin{abstract}
We aimed to verify whether morphoanatomic alterations occur in response to excess iron, in roots of Setaria parviflora and Paspallum urvillei (Poaceae), and to localize the presence of the sites of iron accumulation. Plants were subjected to $0.009,1,2,4$, and $7 \mathrm{mM}$ Fe-EDTA in nutrient solution. Both species presented iron contents in the roots above the critical toxicity level. The presence of iron plaque on roots of the two species was confirmed, and it may have reduced iron absorption by the plants. Roots from the two species showed typical visual symptoms of stress by excess iron: change in color and mucilaginous and flaccid appearance. Anatomical damage was observed in both species: aerenchyma disruption, alterations in endodermal cells, and irregular shape of both vessel and sieve tube elements. The metal was histolocalized in the cortex and in protoxylem and metaxylem cell walls in both species, which suggests a detoxification strategy for the excess iron. Phenolic compounds were not histolocalized in roots. Microscopic analyses were therefore effective in evaluating the real damage caused by excess iron.
\end{abstract}

Keywords Setaria parviflora · Paspallum urvillei · Poaceae · Symptomatology $\cdot$ Histochemistry $\cdot$ Energy dispersive X-ray (EDX)

Responsible editor: Elena Maestri

T. O. de Araújo • L. de Freitas-Silva • B. V. N. Santana • K. N. Kuki • A. A. Azevedo • L. C. da Silva $(\bowtie)$

Universidade Federal de Viçosa, 36570-900 Viçosa, MG, Brazil

e-mail: luzimar@ufv.br

E. G. Pereira

Universidade Federal de Viçosa, Campus de Florestal, 35690-000 Florestal, MG, Brazil

\section{Introduction}

Iron $(\mathrm{Fe})$ is an essential nutrient for plant growth and development, taking part in several biochemical processes in plant cells (Stephan 2002). Despite being abundant in soil, iron originates iron hydroxides, which are highly insoluble, thus being generally unavailable to plants (Nozoye et al. 2011).

Fe can affect cellular homeostasis and cause toxicity to plants (Williams et al. 2000; Ducic and Polle 2005). However, environments with high levels of metals in the soil may be propitious to the selection of tolerant plants, which in turn may possess strategies that allow them to survive under this kind of stress (Macnair 1993; Milner and Kochian 2008).

Grass species Setaria parviflora (Poir.) Kerguélen and Paspalum urvillei Steudel are commonly found spontaneously at the margins of a decantation pond, in an iron ore pelletizing industry located in the community of Ubu, Anchieta city, state of Espírito Santo, Brazil. Besides tolerating high $\mathrm{Fe}$ concentrations in the substrate, both species accumulate in their tissue iron contents above the toxicity limit, which according to Marschner (1995) is $500 \mathrm{mg} \mathrm{kg}{ }^{-1}$, without altering their growth (Araújo et al. 2014). Species exposed to high iron concentrations may exhibit characteristic visual toxicity symptoms (Santana et al. 2014), even when not presenting changes in their growth (Araújo et al. 2014).

Visual analysis of shoots is a quick alternative that assists in the perception of plant stress (Fontes 2006). Other species accumulating high pollutant concentrations in their tissues might not exhibit visual damage, yet present structural damage in root and shoot tissues (Hecht-Buchholz 1983). Thus, microscopic analyses may assist in injury prognosis and in the assessment of the real damage caused by excessive pollutants (Silva et al. 2000; Sant'Anna-Santos et al. 2006; Sant'Anna- 
Santos and Azevedo 2007; Giampaoli et al. 2012; Gomes et al. 2012).

The absorption of high iron concentrations causes both an increased production of reactive oxygen species (ROS) and oxidative stress to cells (Becana et al. 1998; Tsai and Huang 2006). Improving antioxidant systems (either enzymatic or nonenzymatic), which would neutralize such stress, is one of the strategies used by tolerant plants (Sinha et al. 1997; Sytar et al. 2013). An example of a nonenzymatic mechanism is increased production of phenolic compounds. These antioxidants tend to chelate $\mathrm{Fe}$, thus preventing the formation of free radicals (Michalak 2006).

This study is different from the other studies with P. urvillei and S. parviflora, because we focus in the root, which is the first organ of the plant to get in contact with excess metals in the substrate, and in response, it may present anatomical alterations and consequently several effects in the plant body (Lux et al. 2010). Furthermore, in this organ, there could occur the formation of iron plaque, which is the consequence of oxidation of ferrous ion to ferric ion, followed by precipitation of iron oxide hydroxide on the root surface (Taylor and Crowder 1983). The presence of the iron plaque can either reduce or increase the absorption of certain nutrients (Zhang et al. 1999). Thus, to understand the mechanisms of iron absorption and accumulation, it is essential to conduct a structural analysis on the formation process of the iron plaque on the roots, as well as to know the main sites of iron accumulation in plant tissues (Siqueira-Silva et al. 2012).

The hypothesis tested was that S. parviflora and P. urvillei would not present severe structural damage in the roots in response to excess iron, due to their natural survival in an ironrich environment. We aimed to verify whether morphoanatomical alterations would occur in the species roots in response to high iron levels in nutrient solution and to localize the sites of iron accumulation.

\section{Material and methods}

Cultivation conditions and treatment application

The experiment was carried out in a greenhouse at Universidade Federal de Viçosa (UFV), in Viçosa city, state of Minas Gerais, Brazil ( $649 \mathrm{~m}$ high, 20 $0^{\circ} 45^{\prime} 20^{\prime \prime} \mathrm{S}$ and $42^{\circ} 52^{\prime}$ $40^{\prime \prime} \mathrm{N}$ ). Individuals of $S$. parviflora (Poir.) Kerguélen and P. urvillei Steudel (Poaceae) were collected at the decantation pond margins of an iron ore pelletizing industry located in the community of Ubu, Anchieta city, state of Espírito Santo, Brazil ( $20^{\circ} 46^{\prime} 21.0^{\prime \prime} \mathrm{S}$ and $\left.40^{\circ} 34^{\prime} 52.3^{\prime \prime} \mathrm{W}\right)$. This pond is supplied with water from the iron ore pelletizing industry system and from the iron ore pipeline, and therefore is rich in iron particles. Species identity was confirmed by specialist Hilda Maria Longhi Wagner, and specimens were deposited in
Herbarium VIC (UFV) with numbers 36801 and 36802 for P. urvillei and $S$. parviflora, respectively.

Individuals were transplanted and cultivated in 8-L plastic pots containing conventional substrate (clay soil/sand/bovine manure-3:1:1) for approximately 90 days. Then, clumps of each species were carefully extracted from the substrate, using running water to separate the roots from it. After a visual standardization based on clump volume, a pruning was carried out on roots and culms (leaving approximately $4 \mathrm{~cm}$ of both roots and shoots). Clumps were transferred to 5 -L polystyrene boxes and kept in Hoagland nutrient solution (Hoagland and Arnon 1950), at half ionic strength, with $\mathrm{pH} 5.0$ (adjusted every 2 days using $\mathrm{NaOH} 1 \mathrm{~N}$ and $\mathrm{HCl} 1 \mathrm{~N}$ ) and constant aeration. Solution volume was completed with deionized water whenever necessary in order to reset transpiration demand, and the solution was renewed on a weekly basis. During 40 days, plants were pruned twice at culm height for homogenization, as described above, before treatment application.

In order to avoid undesirable stress due to sudden exposition to high iron doses in the nutrient solution, an acclimatization was carried out, by gradually increasing iron content in the solution until reaching the final concentrations of $1,2,4$, and $7 \mathrm{mM}$. During the acclimatization period, the solution was renewed every $12 \mathrm{~h}$. Initially, an increment of $0.25 \mathrm{mM} \mathrm{Fe}-$ EDTA was performed until all treatments reached $1 \mathrm{mM} \mathrm{Fe}$ EDTA (except for the control treatment). Then, the final concentration values of each treatment were established with the increment of $2 \mathrm{mM}$ (on treatments 2, 4, and $7 \mathrm{mM} \mathrm{Fe}-$ EDTA), $4 \mathrm{mM}$ (on treatments 4 and $7 \mathrm{mM}$ Fe-EDTA), and $7 \mathrm{mM}$ Fe-EDTA (on treatment $7 \mathrm{mM}$ Fe-EDTA only). Time period for plant acclimatization to iron concentrations was $84 \mathrm{~h}$ (3.5 days). These iron concentrations were based on Pereira et al. (2013), who worked with another grass species, Oryza sativa.

After establishment of the final concentrations, the nutrient solution was renewed every 3 days, and $\mathrm{pH}$ was adjusted daily to 5.0 as previously described. Plants remained exposed to treatments during 14 days for anatomical and visual analyses $(n=5)$.

\section{Visual characterization}

At the end of the experiment, visual symptoms caused by the excess iron in roots of $S$. parviflora and P. urvillei were photographed with a digital camera (model Cyber-Shot DSC-W310, Sony Corporation, Japan).

Structural characterization in light microscopy

Root samples with visible symptoms were collected at $5 \mathrm{~cm}$ from root apex from all treatments. These samples were fixed in $2.5 \%$ glutaraldehyde and $4 \%$ paraformaldehyde in a sodium phosphate buffer 0.1 M (pH 7.0) (Karnovsky 1965, 
modified) for $48 \mathrm{~h}$, and stored in $70 \%$ alcohol. Then, they were dehydrated in an ethyl series and embedded in glycol methacrylate (Leica Historesin, Nussloch/Heidelberg, Germany). Transverse sections of roots (6 $\mu \mathrm{m}$ thick) were obtained with an automatic rotary microtome (model RM2155 Leica Microsystems Inc., Deerfield, IL, USA), stained with $0.05 \%$ toluidine blue ( $\mathrm{pH} 4.0$ ) (O’Brien and McCully 1981), and mounted in Permount.

\section{Histochemical analysis}

In order to detect the presence of iron in tissues from roots, after sample fixation in Karnovsky, cross sectioning was performed on roots of plants from treatments $0.009 \mathrm{mM}$ (control) and $7 \mathrm{mM}$ Fe-EDTA. Sections were obtained in a table microtome (model LPC, Rolemberg e Bhering Comércio e Importação LTDA, Belo Horizonte, MG, Brazil). After distilled water rinsing, sections were set in a solution containing $4 \%$ potassium ferricyanide and $4 \%$ hydrochloric acid for $48 \mathrm{~h}$ (Stevens and Chalk 1996, adapted by Silva et al. 2006). This test shows the presence of iron by a blue staining called Prussian Blue. A negative control, in which sections were not exposed to the reaction, was conducted in parallel. After distilled water rinsing, sections were mounted in water.

Detection of phenolic compounds was performed on roots of plants from treatments 0.009 and $7 \mathrm{mM} \mathrm{Fe}$ EDTA. Samples were fixed in a solution of formalin with ferrous sulfate (4\% formaldehyde and $10 \%$ ferrous sulfate) for $24 \mathrm{~h}$ under vacuum. After distilled water rinsing, samples were dehydrated in an ethyl/buthyl series (Johansen 1940) and embedded in histological paraffin. Samples were then cut on a rotary microtome (8 $\mu \mathrm{m}$ thick), deparaffinized, and microscopic glass slides were mounted in Permount. The control test was performed with samples previously stored in methanol for $72 \mathrm{~h}$ under vacuum for removal of the phenolic compounds.

Results of all cited anatomical analyses were registered in a photomicroscope (model AX70RF, Olympus Optical, Tokyo, Japan) equipped with a U-photo system and coupled to an AxioCam camera (Carl Zeiss, Jena, Germany), and image acquisition was carried out using software AxioVision LE (Carl Zeiss, Jena, Germany) and a microcomputer, at Laboratory of Plant Anatomy of UFV.

Structural characterization in scanning electron microscopy and energy dispersive X-ray microanalysis (EDX)

For analysis of the root surface, root samples of both species were collected at $1 \mathrm{~cm}$ from root apex, in plants from treatments 0.009 and $7 \mathrm{mM}$ Fe-EDTA, and fixed in Karnovsky (Karnovsky 1965, modified). Samples were dehydrated in an ethyl series and critical point dried with liquid $\mathrm{CO}_{2}$ (model CPD 030, Bal-Tec, Liechtenstein). Dry fragments were fixed on metal supports. Some fragments from each treatment were sputter-coated with gold (model FDU 010, Balzers, Liechtenstein) for analysis in scanning electron microscopy, while other fragments were sputter-coated with carbon for microanalysis by EDX. Both are qualitative analyses. Photographic documentation was carried out in a SEM (Leo, model 1430VP, Cambridge, England) operated at $20 \mathrm{kV}$ with an X-ray probe coupled.

Statistical analysis

The experiment was mounted in a factorial scheme and randomized block design, with two species ( $S$. parviflora and P. urvillei), five treatments $(0.009,1,2,4$, and $7 \mathrm{mM} \mathrm{Fe}-$ EDTA), and five repetitions.

\section{Results}

\section{Visual characterization}

Visual alterations were observed in roots of both $S$. parviflora and $P$. urvillei in all excess iron concentration. As iron concentration in the solution increased, we noticed an intensification of the yellowish color in P. urvillei roots (Fig. 1a, b, c, e) and of the orange color in S. parviflora roots (Fig. 1f, g, $h, j$ ). The organ presented, in both species, a mucilaginous and flaccid appearance. In $P$. urvillei roots, necrotic spots could also be observed (Fig. 1e).

\section{Structural characterization in light microscopy}

Roots of $S$. parviflora and $P$. urvillei present an uniseriate epidermis. In the root cortex of both species, there is an aerenchyma and an uniseriate endodermis composed of compact cells with an "U"-shaped cell wall thickening. In P. urvillei, there is an exodermis, which is composed of one layer of tabular cells. Root is polyarch with an exarch xylem and the presence of a pith. Pericycle is also uniseriate (Fig. 2a, e).

In both studied species, anatomical alterations were observed, a greater intensity of damage taking place with increasing Fe-EDTA concentrations. S. parviflora and P. urvillei presented aerenchyma disruption (Fig. 2f), alterations in endodermal cells (Fig. $2 \mathrm{~g}$ ), and alterations in the shape of both vessel and sieve tube elements (Fig. 2f, g). P. urvillei presented protoplast retraction in cortical and endodermal cells (Fig. 2c), formation of a cicatrization tissue in the cortex (Fig. 2b), and collapse of pith cells (Fig. 2d). In S. parviflora, irregularities in the shape of pericycle cells were also observed (Fig. 2g). 


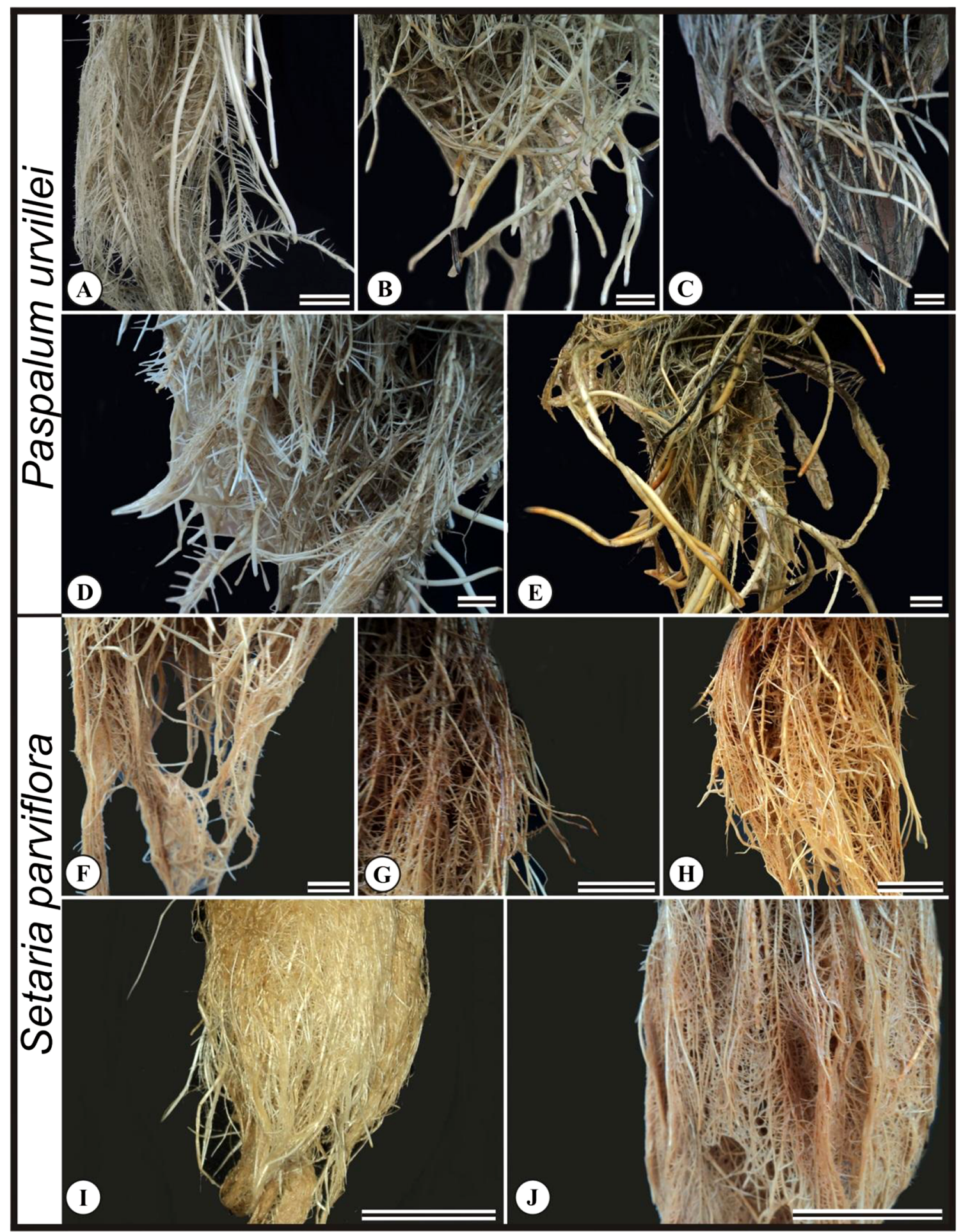

Fig. 1 Root system of Paspalum urvillei $(\mathbf{a}-\mathbf{e})$ and Setaria parviflora $(\mathbf{f}-\mathbf{j})$, subjected to $1 \mathrm{mM}(\mathbf{a}, \mathbf{f}), 2 \mathrm{mM}(\mathbf{b}, \mathbf{g}), 4 \mathrm{mM}(\mathbf{c}, \mathbf{h})$, and $7 \mathrm{mM}(\mathbf{e}, \mathbf{j})$ FeEDTA. Control treatment with $0.009 \mathrm{mM}$ Fe-EDTA (d, i). Bars $(\mathbf{a}-\mathbf{e}, \mathbf{g}-\mathbf{j}) 20 \mathrm{~mm}$. i $100 \mathrm{~mm}$

Histochemical analysis

At control treatment, $P$. urvillei roots showed strong reaction in epidermal and exodermal cells and weak reaction in cortex, pericycle, xylem, and phloem cells (Fig. 3a). As for
S. parviflora, roots presented strong reaction in epidermal cells and weak reaction in cortex cells (Fig. 3d).

In $P$. urvillei, at concentration $7 \mathrm{mM}$ Fe-EDTA, epidermis, aerenchyma, endodermis, pericycle, phloem, and protoxylem showed strong reaction (Figs. 3b, c). At this concentration, 


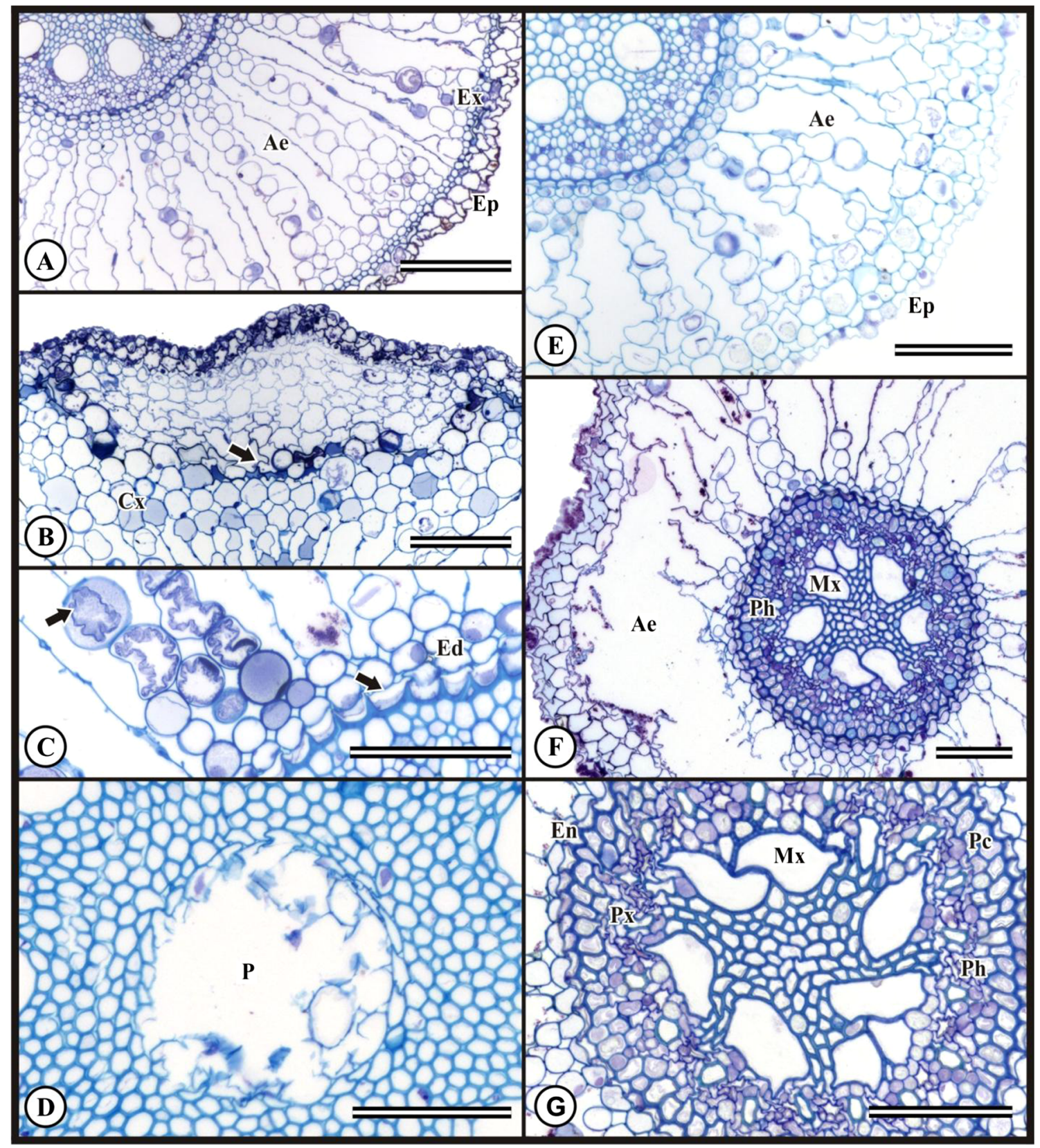

Fig. 2 Anatomical alterations in roots of Paspalum urvillei (a-d) and Setaria parviflora $(\mathbf{e}-\mathbf{g})$ in cross sections. a, e Control treatment, with $0.009 \mathrm{mM}$ Fe-EDTA in nutrient solution. b-d, f, $\mathbf{g}$ Treatment with $7 \mathrm{mM}$ Fe-EDTA in nutrient solution. b Formation of a cicatrization tissue in cortical cells. c Protoplast retraction of aerenchyma and endodermis cells.

S. parviflora showed strong reaction in epidermis, phloem, and xylem cells (Fig. 3e, f). The two species showed a positive reaction for iron histolocalization in cortex cells and in protoxylem and metaxylem cell walls (Fig. 3b, e, detail). The presence of iron was not detected in the pith of either species or in the endodermis of $P$. urvillei.

In both species, roots from the treatments analyzed showed a negative result in the histochemical test for detection of phenolic compounds (not shown). d Collapse of pith cells. f Aerenchyma disruption. $\mathbf{g}$ Alteration in endodermis and pericycle cells. f, $\mathbf{g}$ Irregular shape of both vessel and sieve tube elements. Ep epidermis, $E x$ exodermis, $C x$ cortex, $A e$ aerenchyma, $E d$ endodermis, $P c$ pericycle, $M x$ metaxylem, $P x$ protoxylem, $P h$ phloem, $P$ pith. Bars a, b $200 \mu \mathrm{m}, \mathbf{c}-\mathbf{g} 100 \mu \mathrm{m}$

Structural characterization in scanning electron microscopy and energy dispersive X-ray microanalysis

Root surface in plants of both $P$. urvillei and S. parviflora from the control treatment in scanning electron microscopy (SEM) showed epidermal cells with normal appearance, with distinguishable delimitations between cells (Fig. 4a, c). At concentration $7 \mathrm{mM}$ Fe-EDTA, roots of the two species presented deposition of an external substance heterogeneously 
Fig. 3 Iron histolocalization in roots of Paspalum urvillei $(\mathbf{a}-\mathbf{c})$ and Setaria parviflora $(\mathbf{d}-\mathbf{f})$, cultivated with $7 \mathrm{mM}$ Fe-EDTA $(\mathbf{b}, \mathbf{c}, \mathbf{e}, \mathbf{f})$ in nutrient solution, after $48 \mathrm{~h}$ of exposure to the Prussian Blue reagent. a, d Control treatment with $0.009 \mathrm{mM} \mathrm{Fe}$ EDTA. Ep epidermis, Ex exodermis, $C x$ cortex, $P c$ pericycle, $V c$ vascular cylinder, $E d$ endodermis, $P h$ phloem, $P x$ protoxylem, $M x$ metaxylem, $X y$ xylem. Bars $100 \mu \mathrm{m}$ (details at $\mathbf{b}$ and $\mathbf{e}$ ) $500 \mu \mathrm{m}$

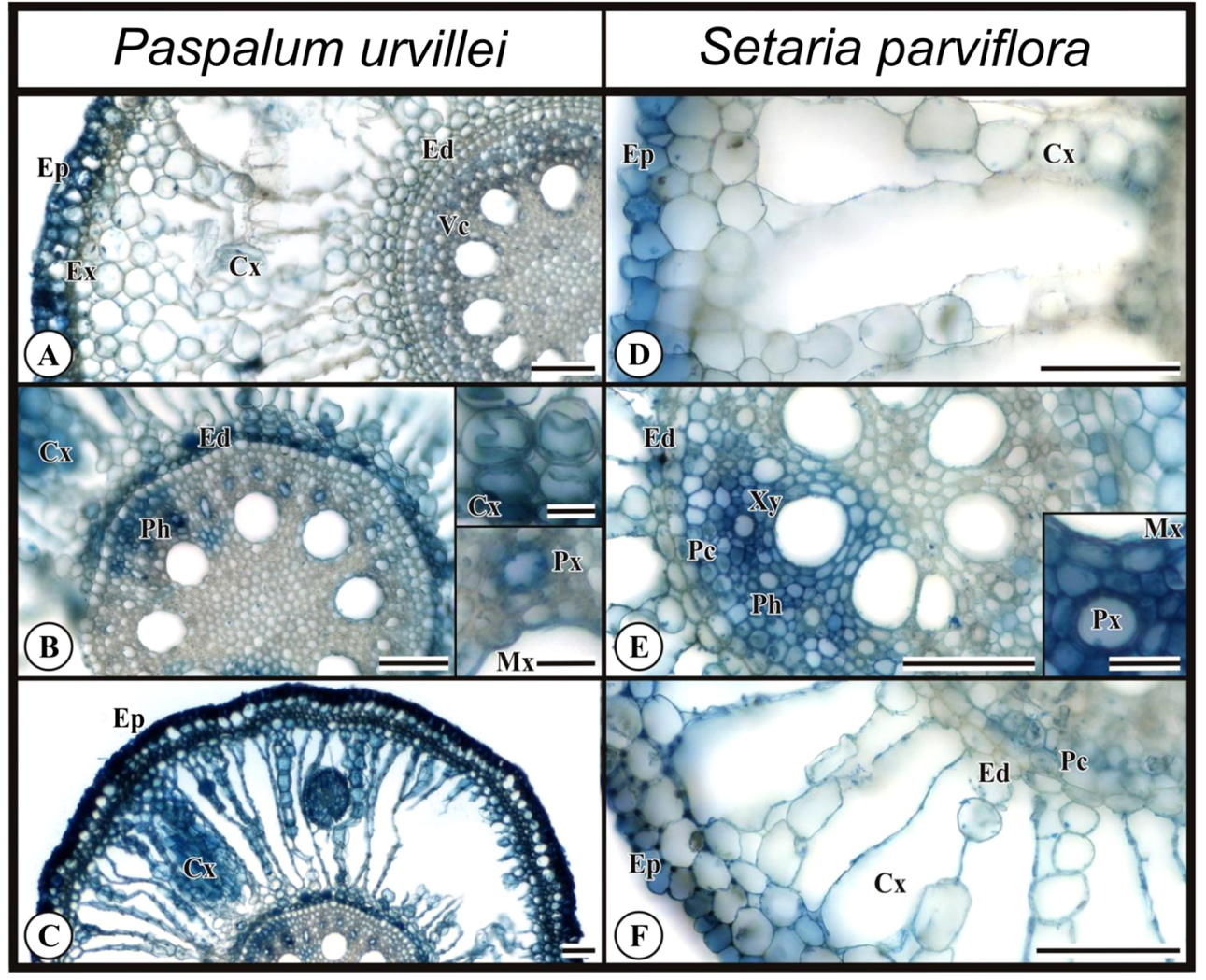

distributed over the root surface, i.e., iron plaque, which hampered the visualization of limits between cells (Fig. 4b, d). Additionally, in P. urvillei, a cracked appearance was observed in the root surface.

EDX of root surface (Fig. 5a, d) in plants from treatment $7 \mathrm{mM} \mathrm{Fe}$-EDTA (Fig. 5c, f) showed an increase in the amount of superficial iron of $98.82 \%$ in P. urvillei and $97.51 \%$ in $S$. parviflora, in relation to plants from the control treatment (Fig. 5b, e).

\section{Discussion}

P. urvillei and S. parviflora are both species that tolerate and accumulate in their root iron amounts above the toxicity limit (500 $\mathrm{mg} \mathrm{kg}^{-1}$ ) (Marschner 1995), as already verified by Santana et al. (2014), who studied the iron effects on these two species with the same exposure time as the one used in our study. The high iron content caused morphological and anatomical alterations in roots of the two studied species.

SEM and EDX analyses confirmed the presence of iron plaque, which was the cause of the color change in roots of P. urvillei and S. parviflora. The aerenchyma in roots of both species may have favored the formation of iron plaque, which then resulted in visual changes. Aerenchyma propitiates the development of an oxidation zone on roots (Evans 2003), which contributes to the oxidation of $\mathrm{Fe}^{2+}$ from the nutrient solution to $\mathrm{Fe}^{3+}$, and also to the precipitation of iron oxyhydroxides on the root surface (Chen et al. 1980).

The role of the iron plaque on the root surface remains controversial. Some authors state that the plaque may either decrease or increase absorption of certain nutrients and metals (Jiang et al. 2009; Seyfferth et al. 2010; Wang et al. 2010; Zhong et al. 2010; Liu et al. 2011). In a study with the same two species and same Fe-EDTA concentrations (Araújo et al. 2014), it has been verified on root surfaces the deposition of high iron contents, i.e., part of the Fe available for absorption in the nutrient solution precipitated as iron oxide hydroxide, thus becoming unavailable for absorption by the two species. However, although the iron plaque may have reduced $\mathrm{Fe}$ absorption, $P$. urvillei and S. parviflora both accumulated high Fe contents within the roots.

In order to maintain cellular homeostasis, tolerant plants can sequester the excess of heavy metals in the vacuole (Pich et al. 2001) and cell wall (Yang et al. 2011). Thus, the positive histolocalization of iron in cortex cells and in protoxylem and metaxylem cell walls of $P$. urvillei and $S$. parviflora suggests a detoxification strategy in these species for the excess iron.

In roots, certain tissues, e.g., the endodermis, can act as barriers and therefore function as a protection against the toxic effects caused by heavy metals (Lux et al. 2004). Despite this, we observed damage in cells of the vascular 
Fig. 4 Roots of Paspalum urvillei $(\mathbf{a}, \mathbf{b})$ and Setaria parviflora $(\mathbf{c}, \mathbf{d})$ from control treatment $(0.009 \mathrm{mM}$ Fe-EDTA in nutrient solution) $(\mathbf{a}, \mathbf{c})$ and treatment with $7 \mathrm{mM}$ Fe-EDTA in nutrient solution $(\mathbf{b}, \mathbf{d})$, in scanning electron microscopy. $E p$ epidermis, Ip iron plaque. Bars a, c $20 \mu \mathrm{m} ; \mathbf{b}, \mathbf{d} 100 \mu \mathrm{m}$
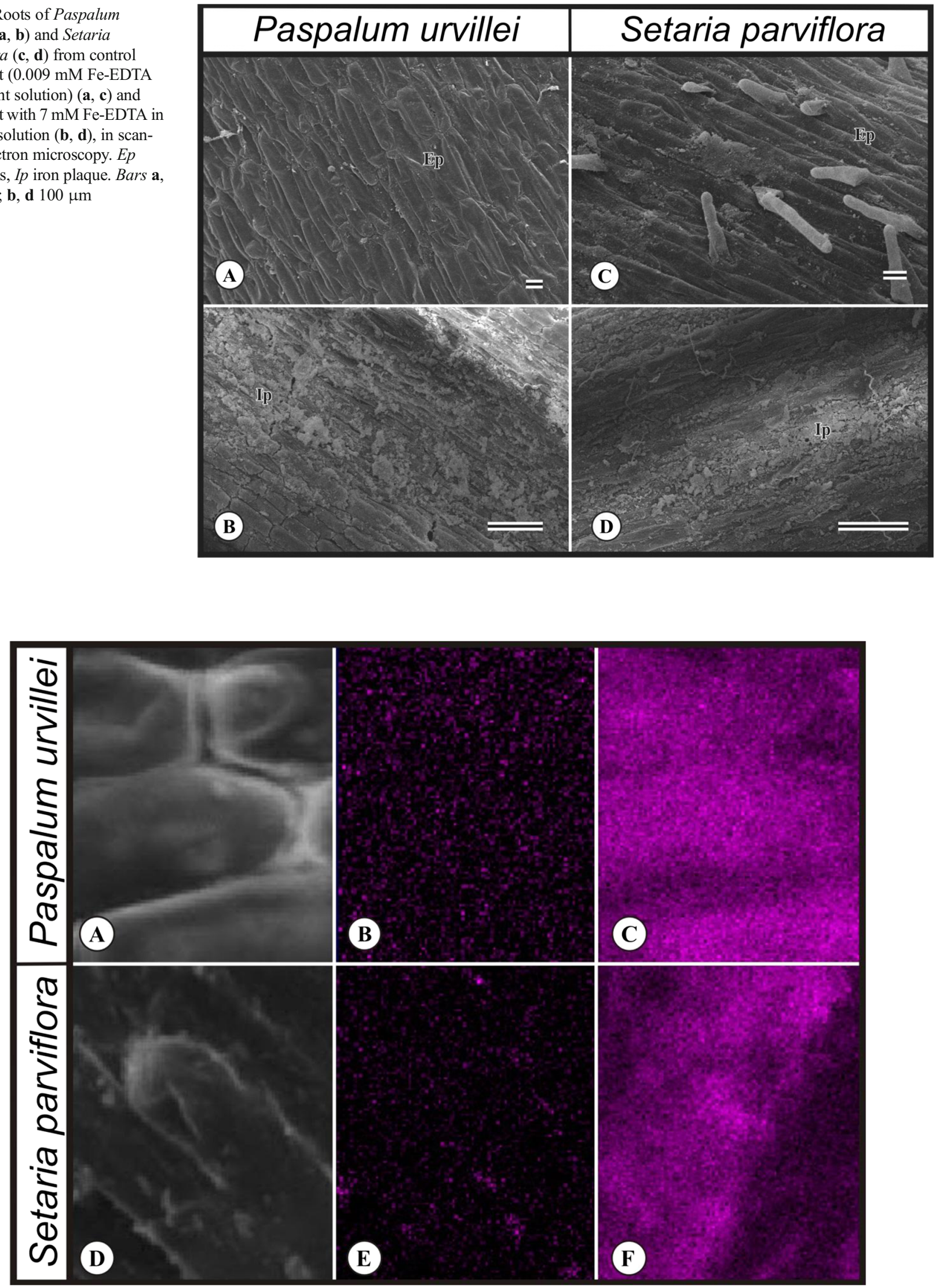

Fig. 5 Roots of Paspalum urvillei $(\mathbf{a}-\mathbf{c})$ and Setaria parviflora $(\mathbf{d}-\mathbf{f})$ from control treatment $(0.009 \mathrm{mM}$ Fe-EDTA in nutrient solution) (b, e) and treatment with $7 \mathrm{mM}$ Fe-EDTA in nutrient solution $(\mathbf{c}, \mathbf{f})$, in energy dispersive X-ray microanalysis. Pink dots mark the presence of iron on root surface 
cylinder in the two studied species, which therefore suggests that such barriers were not effective against iron toxicity. The cicatrization tissue in $P$. urvillei also acts as a barrier that would prevent damage progress toward healthy tissues (Siqueira-Silva et al. 2012), as observed in some plant species exposed to different pollutants (Silva et al. 2005; Sant'AnnaSantos et al. 2006). In our study, this tissue was not effective on barring the entry of $\mathrm{Fe}$, as demonstrated by the presence of structural damage.

Decreasing levels of both copper and potassium in root dry matter (Araújo et al. 2014) of P. urvillei and S. parviflora have been found at treatments with high Fe-EDTA concentrations in hydroponic solution. Thus, the anatomical alterations observed in roots of P. urvillei and S. parviflora are likely to have occurred due to accumulation of high iron levels in tissues and/or to nutritional disorder resulting from the deposition of iron plaque on the roots. Reduction in the amounts of copper and potassium can compromise xylem lignification. According to Marschner (1995), copper and/or potassium deficiency in higher plants causes insufficiency in lignification of xylem vessels and structural weakening of the cell wall. Thus, the shape deformation in xylem cells detected in roots of P. urvillei and S. parviflora may have been caused by problems in the synthesis of lignin, as a consequence of nutritional disorder.

Certain results observed in the two species, such as protoplast retraction and cell collapse, may have resulted from plasma membrane deterioration. This phenomenon is likely to occur at high iron content conditions, in which there is a predisposition to an increased production of ROS (Briat et al. 2010), which in turn can induce peroxidation of lipids that compose plasma membrane (Sinha et al. 1997). Plasma membrane deterioration may also have influenced the absorption of some nutrients, since both species presented nutritional disorder when subjected to excess iron (Araújo et al. 2014).

The impending action of oxidative stress in cells can be mitigated by strategies like chelation of heavy metals by organic molecules such as phenolic compounds, which can directly neutralize ROS (Sytar et al. 2013). However, in the studied species, such compounds were not detected by histochemical analysis in tissues with high iron contents. P. urvillei and S. parviflora may possibly possess some other effective kind of antioxidant mechanism, like enzyme activity, since complete development of their life cycle occurs in a site with excess iron. We suggest that further studies that would elucidate the antioxidant system of the two species should be performed. We also suggest that additional experiments should be conducted with a longer period of exposure to $\mathrm{Fe}$ than the one presented in this paper, which would lead to a better understanding of the behavior of $P$. urvillei and S. parviflora in iron-rich environments.

\section{Conclusions}

P. urvillei and S. parviflora showed morphological and anatomical alterations caused by high iron amounts in root tissues. Both species presented typical visual symptoms of stress by excess iron. However, considering the high $\mathrm{Fe}$ contents accumulated, these symptoms were not severe enough as to cause, for example, such a cell collapse that would damage the entire organ

The positive histolocalization of iron in cortex cells and in protoxylem and metaxylem cell walls in $P$. urvillei and S. parviflora suggests a detoxification strategy in these species for the excess iron. Furthermore, the two species may possess strategies that allow iron compartmentalization, and consequently their survival in environments with high iron levels, even presenting visual symptoms and anatomical damage.

Anatomical damage was observed in both species. Microscopic analyses were therefore effective in evaluating the real damage caused by excess iron. Since both species develop naturally in an iron-rich environment and are able to complete their life cycle, anatomical damage was not so severe as to compromise the development of $P$. urvillei and S. parviflora.

Acknowledgments The authors thank Coordenação de Aperfeiçoamento de Pessoal de Nível Superior (CAPES) for the approval of a PNADB Project (Programa Nacional de Apoio e Desenvolvimento da Botânica); Conselho Nacional de Desenvolvimento Científico e Tecnológico (CNPq) for the approval of a SISBIOTA-BRASIL (proc. CNPq 563335/2010-6; proc. FAPESP 2010/52319-6) Project and for the Research Productivity Scholarships granted to L.C. Silva (309170/20125) and A.A. Azevedo (307538/2010-9); Fundação de Amparo à Pesquisa do Estado de Minas Gerais (FAPEMIG) for the approval of projects CRA-APQ-01361-12 and RDP-00195-10; Secretaria de Estado de Ciência, Tecnologia e Ensino Superior (SECTES) and Projeto Floresta Escola, for financial support; Hilda Maria Longhi Wagner, for species identification; and Núcleo de Microscopia e Microanálise of Universidade Federal de Viçosa (UFV).

\section{References}

Adamski JM, Danieloski R, Deuner S, Braga EJB, Castro LAS, Peters JA (2012) Responses to excess iron in sweet potato: impacts on growth, enzyme activities, mineral concentrations, and anatomy. Acta Physiol Plant 34:1827-1836

Araújo TO, Freitas-Silva L, Santana BVN, Kuki KN, Pereira EG, Azevedo AA, Silva LC (2014) Tolerance to iron accumulation and its effects on mineral composition and growth of two grass species. Environ Sci Pollut Res 21:2777-2784

Becana M, Moran JF, Iturbe-Ormaetxe I (1998) Iron-dependent oxygen free radical generation in plants subjected to environmental stress: toxicity and antioxidant protection. Plant Soil 201:137-147

Briat J, Ravet K, Arnaud N, Duc C, Boucherez J, Touraine B, Cellier F, Gaymard F (2010) New insights into ferritin synthesis and function highlight a link between iron homeostasis and oxidative stress in plants. Ann Bot Lond 105:811-822 
Chen CC, Dixon JB, Turner FT (1980) Iron coatings on rice roots: morphology and models of development. Soil Sci Soc Am J 44: 1113-1119

Ducic T, Polle A (2005) Transport and detoxification of manganese and copper in plants. Braz J Plant Physiol 17:103-112

Evans DE (2003) Aerenchyma formation. New Phytol 161:35-49

Fontes PCR (2006) Diagnosis of Nutritional Status of Plants.Viçosa: UFV (In Portuguese)

Giampaoli P, Tresmondi F, Lima GPP, Kanashiro S, Alves ES, Domingos M, Tavares AR (2012) Analysis of tolerance to copper and zinc in Aechmea blanchetiana grown in vitro. Biol Plant 56:83-88

Gomes MP, Carvalho M, Marques TCLLSM, Duarte DM, Nogueira COG, Soares AM, Garcia QS (2012) Arsenic-sensitivity in Anadenanthera peregrina due to arsenic-induced lipid peroxidation. Int J Appl Sci Technol 2:55-63

Hecht-Buchholz C (1983) Light and electron microscopic investigations of the reactions of various genotypes to nutritional disorders. Plant Soil 72:151-165

Hoagland DR, Arnon DI (1950) The water culture method for growing plants without soil. California Agricultural Experiment Station, Berkeley

Jiang FY, Chen X, Luo AC (2009) Iron plaque formation on wetland plants and its influence on phosphorus, calcium and metal uptake. Aquat Ecol 43:879-890

Johansen DA (1940) Plant microtechnique. Mc Graw Hill, New York

Karnovsky MJ (1965) A formaldehyde-glutaraldehyde fixative of high osmolarity for use in electron microscopy. J Cell Biol 27:137138

Liu J, Leng X, Wang M, Zhu Z, Dai Q (2011) Iron plaque formation on roots of different rice cultivars and the relation with lead uptake. Ecotoxicol Environ Saf 74:1304-1309

Lux A, Sottnikova A, Opatrna J, Greger M (2004) Differences in structure of adventitious roots in Salix clones with contrasting characteristics of cadmium accumulation and sensitivity. Physiol Plant 120: 537-545

Lux A, Martinka M, Vaculík M, White PJ (2010) Root responses to cadmium in the rhizosphere: a review. J Exp Bot 62:21-37

Macnair MR (1993) Tansley Review No. 49: the genetics of metal tolerance in vascular plants. New Phytol 124:541-559

Marschner H (1995) Mineral nutrition of higher plant. Academic, NewYork

Michalak A (2006) Phenolic compounds and their antioxidant activity in plants growing under heavy metal stress. Pol J Environ Stud 15: $523-530$

Milner MJ, Kochian LV (2008) Investigating heavy-metal hyperaccumulation using Thlaspi caerulescens as a model system. Ann Bot Lond 102:3-13

Nozoye N, Nagasaka S, Kobayashi T, Takahashi M, Sato Y, Sato Y, Uozumi N, Nakanishi H, Nishizawa NK (2011) Phytosiderophore efflux transporters are crucial for iron acquisition in graminaceous plants. J Biol Chem 286:5446-5454

O'Brien TP, Mccully ME (1981) The study of plant structure principles and selected methods, Melbourne, Termarcarphi Pty. Ltd

Pereira EG, Oliva MO, Rosado-Souza L, Mendes GC, Colares DS, Stopato CH, Almeida AM (2013) Iron excess affects rice photosynthesis through stomatal and non-stomatal limitations. Plant Sci 201202:81-92

Pich A, Manteuffel R, Hillmer S, Scholz G, Schmidt W (2001) Fe homeostasis in plant cells: does nicotianamine play multiple roles in the regulation of cytoplasmic Fe concentration? Planta 213: $967-76$
Sant'Anna-Santos BF, Azevedo AA (2007) Aspectos morfoanatômicos da fitotoxidez do flúor em duas espécies tropicais. Rev Bras Biochem 5:48-50

Sant'Anna-Santos BF, Silva LC, Azevedo AA, Araújo JM, Alves EF, Silva AM, Aguiar RM (2006) Effects of simulated acid rain on the foliar micromorphology and anatomy of tree tropical species. Environ Exp Bot 58:158-168

Santana BVN, Araújo TO, Andrade GC, Freitas-Silva L, Kuki KN, Pereira EG, Azevedo AA, Silva LC (2014) Leaf morphoanatomy of species tolerant to excess iron and evaluation of their phytoextraction potential. Environ Sci Pollut Res 21:2550-2562

Seyfferth A, Webb SM, Andrews JC, Fendorf S (2010) Arsenic localization, speciation, and co-occurrence with iron on rice (Oryza sativa $\mathrm{L}$.) roots having variable Fe coatings. Environ Sci Technol 44:8108-8113

Silva LC, Azevedo AA, Silva EAM, Oliva MA (2000) Flúor em chuva simulada: sintomatologia e efeitos sobre a estrutura foliar e o crescimento de plantas arbóreas. Rev Bras Bot 23:383-391

Silva LC, Oliva MA, Azevedo AA, Araújo JM, Aguiar RM (2005) Micromorphological and anatomical alterations caused by simulated acid rain in restinga plants: Eugenia uniflora and Clusia hilariana. Water Air Soil Pollut 168:129-143

Silva LC, Oliva MA, Azevedo AA, Araújo JM (2006) Responses of restinga plant species to pollution from an iron pelletization factory. Water Air Soil Pollut 175:241-256

Sinha S, Gupta M, Chandra P (1997) Oxidative stress induced by iron in Hydrilla verticillata (1.f.) royle: response of antioxidants. Ecotoxicol Environ Saf 38:286-291

Siqueira-Silva AI, Silva LC, Azevedo AA, Oliva MA (2012) Iron plaque formation and morphoanatomy of roots from species of resting subjected to excess iron. Ecotoxicol Environ Saf 78:265-275

Stephan UW (2002) Intra- and intercellular iron trafficking and subcellular compartmentation within roots. Plant Soil 241:19-25

Stevens A, Chalk BT (1996) Pigments and minerals. In: Bancroft JD, Stevens A (eds) Theory and practice of histological techniques, 4th edn. Churchill Livingstone, New York, pp 243-267

Sytar O, Kumar A, Latowski D, Kuczynska P, Strzałka K, Prasad MNV (2013) Heavy metal-induced oxidative damage, defense reactions, and detoxification mechanisms in plants. Acta Physiol Plant 35: 985-999

Taylor GJ, Crowder AA (1983) Use of the DCB technique for extraction of hydrous iron oxides from roots of wetland plants. Am J Bot 70 : 1254-1257

Tsai T, Huang H (2006) Effects of iron excess on cell viability and mitogen-activated protein kinase activation in rice roots. Physiol Plant 127:583-592

Wang ZY, Liu LH, Wen SF, Peng CS, Xing BS, Li FM (2010) Effect of iron plaque on root surfaces on phosphorus uptake of two wetland plants. Coll Environ Sci Eng 31:781-786

Williams LE, Pittman JK, Hall JL (2000) Emerging mechanisms for heavy metal transport in plants. BBA Biomembr 1465:104-126

Yang JL, Zhu XF, Peng YX, Zheng C, Li GX, Liu Y, Shi YZ, Zheng SJ (2011) Cell wall hemicellulose contributes significantly to aluminum adsorption and root growth in Arabidopsis. Plant Physiol 155: $1885-1892$

Zhang X, Zhang F, Mao D (1999) Effect of iron plaque outside roots on nutrient uptake by rice (Oryza sativa L.): phosphorus uptake. Plant Soil 209:187-192

Zhong S, Shi J, Xu J (2010) Influence of iron plaque on accumulation of lead by yellow flag (Iris pseudacorus L.) grown in artificial $\mathrm{Pb}-$ contaminated soil. J Soil Sediment 10:964-970 